\title{
ANALISIS HADITS AKAD IJARAH, IJARAH MUNTAHIYAH BITTAMLIK DAN IJARAH MAUSHUFAH FI DZIMMAH (TELAAH FATWA DSN-MUI)
}

\author{
Tri Hidayati dan Muhammad Syarif Hidayatullah \\ IAIN Palangka Raya dan UIN Antasari Banjarmasin \\ E-mail: tri.hidayati@iain-palangkaraya.ac.id dan syarif.muhammad849@gmail.com
}

\begin{abstract}
Hadith as the second source of Islamic law, becomes a mandatory content in the fatwa DSN MUI included in the formulation of fatwa Ijarah, IMBT and IMFZ. This paper will attempt to analyze the islamic economic hadith that is the content of legal considerations in fatwas on ijarah, IMBT and IMFZ. The research method applied in this paper is research that explores qualitative data with the type of literature research. The focus of the study in this study is the islamic economic hadiths contained in the DSN-MUI fatwa on ijarah, IMBT and IMFZ. The results of the study showed that the DSN-MUI Fatwa on Ijarah, Ijarah Muntahiyah Bittamlik and ijarah Maushufah $f i$ Dzimmah has accommodated sharia economic hadiths that are the legal basis related to the legality of ijarah, IMBT and IMFZ, so that the hadiths have relevance to the object of fatwa studies. There are hadiths that correlate explicitly with the object of fatwa studies and some are implicitly correlated.
\end{abstract}

Keywords: Hadith, Ijarah, Ijarah Muntahiyah Bittamlik, and Ijarah Maushufah fi Dzimmah.

\begin{abstract}
Abstrak
Hadits sebagai sumber hukum Islam yang kedua, menjadi muatan wajib dalam fatwa DSN MUI termasuk dalam rumusan fatwa Ijarah, IMBT dan IMFZ. Tulisan ini akan berupaya menganalisis hadits ekonomi syariah yang menjadi isi pertimbangan hukum dalam Fatwa tentang ijarah, IMBT dan IMFZ. Metode penelitian yang diterapkan dalam tulisan ini adalah penelitian yang menggali data kualitatif dengan jenis penelitian kepustakaan. Fokus kajian dalam penelitian ini adalah hadits-hadits ekonomi syariah yang terdapat dalam fatwa DSN-MUI tentang ijarah, IMBT dan IMFZ. Hasil pengkajian menunjukkan bahwa Fatwa DSN-MUI tentang Ijarah, Ijarah Muntahiyah Bittamlik dan ijarah Maushufah fi Dzimmah telah mengakomodir hadits-hadits ekonomi syariah yang menjadi landasan hukum terkait legalitas ijarah, IMBT dan IMFZ, sehingga hadits-hadits tersebut memiliki relevansi dengan objek kajian fatwa. Terdapat hadits yang berkorelasi secara eksplisit dengan objek kajian fatwa dan ada pula yang berkorelasi secara implisit.
\end{abstract}

Kata Kunci: Hadits, Ijarah, Ijarah Muntahiyah Bittamlik, dan Ijarah Maushufah fi Dzimmah. 


\section{PENDAHULUAN}

Pengaplikasian fikih muamalah dan etika bisnis Islam dalam wujud ekonomi dan keuangan syariah dewasa ini telah tumbuh secara pesat, diterima secara universal dan diadopsi tidak hanya oleh negara-negara Islam di kawasan Timur Tengah saja, tetapi juga oleh berbagai negara di kawasan Asia, Eropa, dan Amerika (Iskandar \& Aqbar, 2019: 40). Perkembangan hukum di bidang muamalah mengalami perubahan dan inovasi-inovasi disebabkan kompelksitas kebutuhan manusia yang semakin meningkat dan variatif baik kebutuhan pokok, sekunder, hingga tersier. Kondisi ini menuntut agar selalu dilakukan telaah hukum dan inovasi hukum manakala praktik muamalah tersebut tidak pernah dilakukan dan dijelaskan secara gamblang dalam sumber hukum utama Islam yakni Al-Qur'an dan Hadits.

Hadits menempati posisi kedua dalam hirarki hukum Islam setelah AlQur'an yang dipegang sebagai pedoman hidup, sumber hukum, dan ajaran dalam Islam. Sebagai sumber hukum, maka keberadaan haditspun ramai dalam kajian dan perbincangan ilmiah dalam menganalisis kandungannya maupun relasinya dengan ayat suci al-Qur'an (Nur, 2017: 20). Hadits secara mendasar memiliki fungsi lil bayan (menjelaskan) terhadap kandungan al-Qur'an yang kemudian dalam rumusan para ulama diperinci menjadi tiga fungsi yakni sebagai bayan at-ta'kid / bayan at-taqrir (memperkuat pernyataan dalam alQur'an), bayan at-tafsir (memberikan perincian dalam tafsiran ayat-ayat A-Qur'an: menjelaskan yang bersifat mujmal, membatasi yang bersifat mutlak dan mengkhususkan yang bersifat umum) dan bayan at-tasyri' (mewujudkan hukum yang tidak terdapat dalam Al-Qur'an) (Saparullah, 2021, hlm. 63-64).

Salah satu aspek muamalah yang mengalami perkembangan hukum adalah ijarah. Ijarah adalah akad pertukaran manfaat suatu benda atau jasa dengan upah/ biaya sewa. Praktek ijarah telah dilakukan pada masa Nabi SAW dengan berbagai macam cara dan objeknya, semua tergambar dalam banyak hadits. Seiring perubahan zaman, praktik ijarah telah berkembang hingga dikenal dengan sebutan Ijarah Muntahiyah bittamlik (IMBT) dan Ijarah Maushufah Fi Dzimmah (IMFZ).

$$
\text { Lembaga Keuangan Syariah }
$$
berpeluang untuk memperbesar usahanya dengan menggunakan skema Ijarah, IMBT, maupun IMFZ, namun berkewajiban pula untuk patuh dan taat pada prinsip-prinsip hukum muamalah sehingga tidak terjadi praktik riba, maisir, gharar, dan zhalim. Para ulama telah melakukan kajian dan istinbath hukum dengan kesimpulan hukum yang beragam terkait ijarah, IMBT dan IMFZ. Ijtihad yang dilakukan para ulama menerapkan metode istinbath yang telah disepakati dengan sumber hukum al-Qur'an dan hadits. Kajian para ulama tersebutpun pada akhirnya menghasilkan fatwa terkait masalah yang dikaji. Fatwa merupakan instrumen hukum yang keberadaannya menjadi bagian yang urgen dalam kehidupan sosial keagamaan. Fatwa berperan sebagai jawaban atas persoalan hukum yang terjadi ataupun menjadi solusi hukum atas problematika yang dihadapi. Fatwa pula menjadi dasar legalitas dan legitimasi terhadap praktik sosial-ekonomi kontemporer yang ketentuan hukum atas eksistensinya tidak terdapat secara eksplisit di dalam nash (al-Qur'an dan hadits) (Fauzi, 2017: 109-110).

Dewan Syariah Nasional MUI (DSN MUI) memiliki otoritas atau wewenang untuk menetapkan fatwa-fatwa yang berkaitan dengan kegiatan ekonomi dan keuangan syariah. Fatwa DSN MUI bersama KHES menjadi norma hukum di bidang hukum materiil ekonomi syariah (Yasin, 2014: 111). Eksistensi fatwa DSNMUI dalam peraturan perundang-undangan terdapat dalam Undang-undang No. 21 Tahun 2008 tentang perbankan syariah yang menerangkan bahwa prinsip syariah yang dimaksud sebagai dasar bank syariah adalah berdasar fatwa dari lembaga yang 
berwenang dan dalam hal ini disebut adalah Majelis Ulama Indonesia. Fatwa DSN-MUI pun telah diserap kepada Peraturan Bank Indonesia dan Peraturan Otoritas Jasa Keuangan. Fatwa yang telah diadopsi menjadi hukum positif ini diramu kembali mejadi aturan-aturan pada kegiatan berdasarkan prinsip syariah (Habibaty, 2018: 451-452).

DSN MUI telah menetapkan fatwa tentang Ijarah, IMBT, dan IMFZ yang tentunya memuat berbagai hadits muamalah maliyyah sebagai dasar hukum fatwa ekonomi dan keuangan syariah yang dirumuskan. Fatwa-fatwa yang diputuskan dalam rumusannya secara substantif harus memuat dalil-dalil hukum yang menjadi dasar pertimbangan terhadap putusan hukum yang sudah seharusnya keberadaannya memang relevan dengan masalah yang dikaji sehingga dikeluarkannya produk hukum tersebut. Begitu pula fatwa ekonomi dan keuangan syariah yang menjadi otoritas DSN-MUI, secara sistematis dalam rumusan fatwanya berupa isi, mengandung konsideran menimbang, mengingat, memperhatikan dan memutuskan. Konsideran mengingat berisi dasar-dasar hukum yang digunakan yaitu Al-Qur'an, hadits, ijma, qiyas, kaidah fikih dan pendapat para ulama (Seff, 2015: 3). Maka hadits sebagai dalil naqli dan sumber hukum (mashadir al-ahkam) yang kedua setelah al-Qur'an, sebagai muatan fatwa DSN-MUI sudah seharusnya memiliki relevansi dengan masalah yang dikaji dan akan dihasilkan putusan hukum akan masalah tersebut. Jadi fiqh al-hadits pada hadits-hadits yang dicantum memang harus berkorelasi dengan masalah yang akan diberikan fatwa.

Oleh karena itu, tulisan ini akan berupaya menganalisis hadits-hadits dalam fatwa DSN-MUI dengan men-takhrij haditshadits tersebut dari kitab haditsnya dan kemudian menelaah eksistensi hadits tersebut dalam muatan fatwa dengan mencermati korelasi dan relevansi fiqh alhadits-nya dengan objek kajian fatwa.

\section{LITERATURE REVIEW}

Ada beberapa tulisan ilmiah terdahulu berdasarkan penelusuran penulis terkait kajian masalah akad ijarah, ijarah muntahiyah bittamlik dan ijarah maushufah fi dzimmah. Tulisan yang pertama adalah artikel berjudul Penerapan Akad Ijarah Muntahiya Bittamlik (IMBT) pada Transaksi Lembaga Keuangan Syariah yang ditulis oleh Husna Ni'matul Ulya. Tujuan penelitian dalam tulisan ini adalah mendeskripsikan pengaplikasian akad IMBT dalam produk keuangaan yang ada pada Lembaga Keuangan Syariah. Hasil penelitian dalam tulisan ini bahwasanya IMBP diaplikasikan dalam produk pembiayaan lembaga keuangan syariah dan bahwasanya pembiayaan IMBT berbeda dengan leasing (sewa beli), dimana perbedaanya terdapat pada saat pengalihan kepemilikan (Ulya, 2018).

Tulisan yang kedua adalah artikel berjudul Analisis Akad Ijarah Muntahiya Bittamlik (IMBT) dalam Perspektif Hukum Islam dan Hukum Positif di Indonesia yang ditulis oleh Daffa Muhammad Dzubyan, Erina Azzahra dan Melani Puspitasari. Tujuan dalam penelitian ini untuk mengalisis akad Ijarah Muntahiya Bittamlik dalam perspektif hukum Islam (fikih) dan hukum positif di Indonesia. Hasil penelitian dalam tulisan ini menunjukkab bahwa dalam perspektif Hukum Islam (fikih), IMBT telah sesuai dengan hukum perjanjian syariah. Dalam perspektif Hukum Positif Indonesia, akad IMBT termasuk dalam perjanjian tidak bernama pada KUH Perdata (Pasal 1319) yang timbul dari prinsip kebebasan berkontrak (Pasal 1338) dan IMBT juga memenuhi persyaratan perjanjian yang sah (Pasal 1320) sebagai serta perjanjian elemen (Dzubyan, 2019).

Tulisan yang ketiga adalah artikel berjudul Implementasi Akad al-Ijarah alMaushufah fi al-Dzimmah sebagai Alternatif Pembiayaan di Lembaga Keuangan Syariah di Indonesia. Pembahasan dalam artikel ini meneliti 
sejauh mana peran dan implementasi akad Al-Ijarah Al-Maushufah Fi Al-Dzimmah dalam produk dan jasa di perbankan Syariah dan juga meninjau akad Al-Ijarah AlMaushufah Fi Al-Dzimmah dalam kajian fikih muamalah. Hasil kajian menyimpulkan bahwa Akad IMFZ sudah sesuai dengan kajian Fiqh Muamalah. Akad ini dianggap sangat tepat untuk kondisi pembiayaan yang sifat dari manfaatnya masih dalam proses tanggungjawab pemberi sewa (Fuadi, 2019).

Dibandingkan dengan penelitian yang telah disebutkan di atas, pengkajian yang akan dilakukan penulis memiliki perbedaan substansial, karena tulisan yang pertama dan ketiga mengkaji akad IMBT dan IMFZ dari segi aplikasinya pada produk lembaga keuangan syariah, sedangkan tulisan yang kedua fokus mengkaji akad IMBT dalam kajian fikih dan perundangundangan. Pengkajian dalam tulisan ini akan diarahkan pada analisis hadits-hadits ekonomi syariah yang menjadi muatan dalam fatwa DSN-MUI tentang Ijarah, Ijarah Muntahiyah Bittamlik dan ijarah Maushufah fi Dzimmah.

\section{METODE PENELITIAN}

Metode penelitian yang digunakan dalam tulisan ini adalah penelitian yang menggali data kualitatif dengan jenis penelitian kepustakaan (library research). Data yang dikaji dalam tulisan ini adalah data sekunder yang didapatkan melalui studi literatur. Hadits-hadits yang dimuat dalam fatwa DSN-MUI tentang Ijarah, Ijarah Muntahiyah Bittamlik dan ijarah Maushufah fi Dzimmah menjadi objek kajian, oleh karena itu studi literatur dilakukan pada fatwa DSN-MUI, kitab-kitab hadits dan buku serta artikel jurnal yang relevan dengan objek kajian.

\section{KONSEP DASAR}

\section{Konsep Ijarah}

Ijarah secara bahasa bermakna jual beli manfaat, dan secara syara' memiliki makna yang sama dengan bahasa. Menurut ulama Syafi'iyah, ijarah terbagi dua yaitu ijarah 'alal 'ain (penyewaan atas barang) seperti penyewaan barang tidak bergerak, kendaraan, atau orang tertentu; dan ijarah 'ala dzimmah (penyewaan atas tanggungan) contohnya menyewakan binatang untuk fungsi tertentu, menjahit, membangun rumah dan jasa lainnya (Az-Zuhaili, 2011). Wahbah Zuhaili mengemukakan bahwa akad ijarah terhadap manfaat suatu benda ataupun jasa telah disepakati hukumnya boleh oleh para ulama fiqh, kecuali Abu Bakar al-Asham, Ismail bin Ulayyah, Hasan Basri, al-Qasyani, an-Nahrawani, dan Ibnu Kaisan. Golongan yang melarang akad ijarah ini karena menjual manfaat, sementara objek (wujud manfaat-manfaat) itu tidak pernah ada saat akad, hanya seiring berjalan waktu manfaat itu terpenuhi secara bertahap. Dalam hukum jual beli, objek yang diperjualbelikan menurut mereka harus pasti dan nyata ada. Pendapat ini ditentang oleh Ibnu Rusyd yang mengatakan bahwa manfaat itu meskipun belum ada saat akad namun dapat dipastikan tercapai secara umum (AzZuhaili, 2011). Adapun hadits yang dijadikan rujukan para ulama fiqih dalam penentuan kebolehan hukum akad ijarah ini antara lain sebagaimana hadits-hadits yang telah disebutkan di atas.

Ijarah sebagaimana diatur oleh fatwa DSN Nomor 09/DSN-MUI/IV/2000 tentang Pembiayaan Ijarah, yang menyatakan bahwa ijarah adalah "akad pemindahan hak guna (manfaat) atas suatu barang atau jasa dalam waktu tertentu melalui pembayaran sewa/upah, tanpa diikuti dengan pemindahan kepemilikan barang itu sendiri". Definisi ini menunjukkan bahwa ijarah pada dasarnya adalah akad yang hanya mengambil suatu manfaat itu dari suatu benda atau jasa sebagaimana pendapat jumhur ulama, tanpa harus diikuti dengan pemindahan kepemilikan barang itu sendiri. Pemindahan kepemilikan setelah masa sewa manfaat habis boleh dilakukan dengan akad tersendiri melalui skema ijarah muntahiya bittamlik yang telah dilegitimasi melalui fatwa nomor 27/DSN-MUI/III/2002. 


\section{Hadits tentang Ijarah}

Praktek ijarah pada masa Rasulullah dan para sahabat banyak diungkapkan dalam beberapa hadits yang dapat diklasifikasikan menjadi dua, yakni ijarah terkait sewa jasa dan ijarah yang objeknya berupa aset (benda bergerak maupun benda tidak bergerak). Banyak pula hadits yang berbicara batasan dalam melakukan traksaksi ijarah tersebut. Berikut ini landasan hadits ijarah terkait bolehnya upah sebagai amil zakat yang diriwayatkan Imam Muslim (Naisaburi \& Al-Qusairi, 2006):

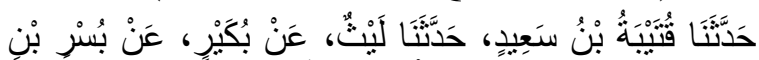

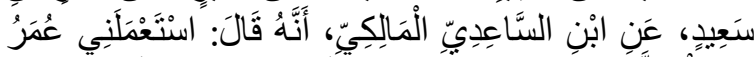

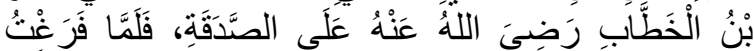

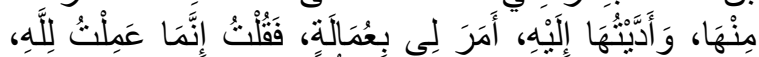

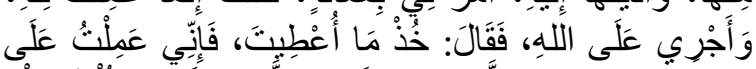

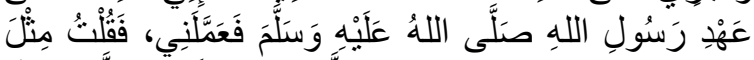

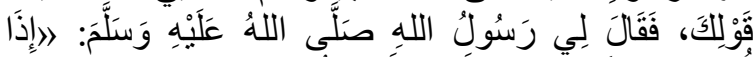

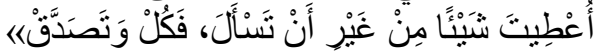

Artinya: Telah menceritakan kepada kami Qutaibah bin Sa'id telah menceritakan kepada kami Laits dari Bukair dari Busr bin Sa'id dari Ibnu As Sa'idi Al Maliki bahwa ia berkata; Umar bin Al Khaththab pernah menugaskanku sebagai amil zakat. Setelah tugas itu selesai kulaksanakan, dan hasil zakat yang kukumpulkan telah kuserahkan kepadanya, maka Umar menyuruhku mengambil bagian amil untukku. Lalu jawabku, "Aku bekerja karena Allah, karena itu upahku pun kuserahkan kepada Allah." Umar berkata, "Ambillah apa yang diberikan kepadamu itu, sesungguhnya aku pernah pula bertugas pada masa Rasulullah shallallahu 'alaihi wasallam sebagai amil zakat. Aku menolak pemberian itu seraya menjawab seperti jawabanmu pula. Maka Rasulullah shallallahu 'alaihi wasallam pun bersabda: 'Apabila kamu diberi orang suatu pemberian tanpa kamu minta, makanlah atau sedekahkanlah."

Hadist lain riwayat Imam Muslim mengkisahkan ijarah terkait jasa bekam yang diriwayatkan oleh Imam Muslim (Naisaburi \& Al-Qusairi, 2006):

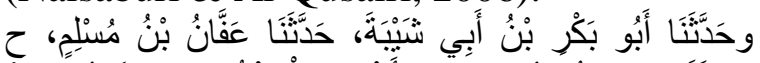

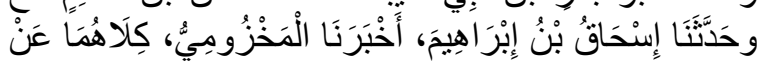

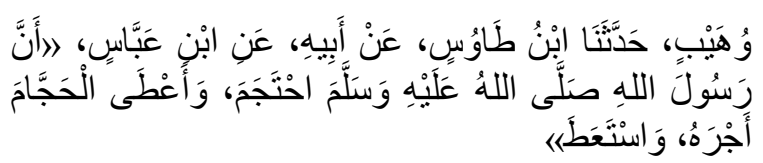

Artinya: Telah menceritakan kepada kami Abu Bakar bin Abu Syaibah, telah menceritakan kepada kami Affan bin Muslim. (Dalam jalur lain disebutkan) Telah menceritakan kepada kami Ishaq bin Ibrahim telah mengabarkan kepada kami Al Mahzumi keduanya dari Wuhaib telah menceritakan kepada kami Ibnu Thawus dari Ayahnya dari Ibnu Abbas, bahwa Rasulullah shallallahu 'alaihi wasallam meminta untuk dibekam, lalu beliau memberi upah kepada tukang bekam."

$$
\text { Dasar hukum ijarah untuk }
$$

pemanfaatan tanah dapat dilihat sebagaimana hadits terkait pemanfaatan tanah riwayat Imam Bukhori (Al-Bukhari, 2000):

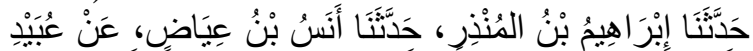

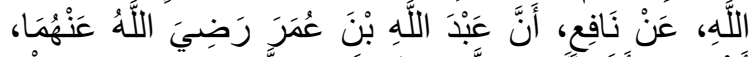

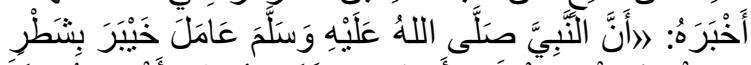

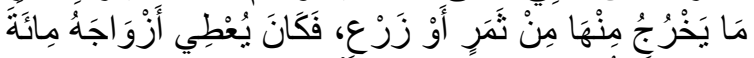

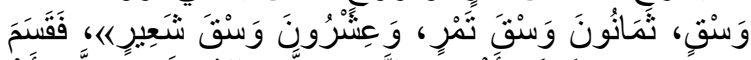

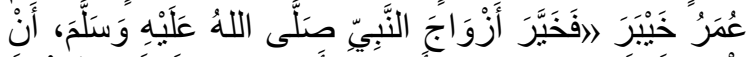

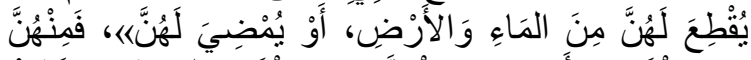

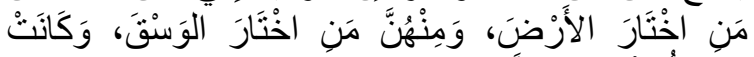

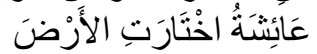

Artinya: Telah menceritakan kepada kami Ibrahim bin Al Mundzir telah menceritakan kepada kami Anas bin 'Iyadh dari 'Ubaidullah dari Nafi' bahwa 'Abdullah bin 'Umar radhiallahu 'anhuma mengabarkannya bahwa Nabi shallallahu 'alaihi wasallam memperkerjakan orang untuk memanfaatkan tanah Khaibar dengan ketentuan separuh dari hasilnya berupa kurma atau sayuran untuk pekerja. Beliau membagikan hasilnya kepada isteri-isteri Beliau sebanyak seratus wasaq, delapan puluh wawsaq kurma dan dua puluh wasaq gandum. Pada zamannya, 'Umar radhiallahu 'anhu membagi-bagikan tanah Khaibar. Maka isteri-isteri Nabi shallallahu 'alaihi wasallam ada yang mendapatkan air (sumur), tanah atau seperti hak mereka sebelumnya. Dan diantara mereka ada yang memilih tanah dan ada juga yang memilih 
menerima haq dari hasilnya. Sedangkan 'Aisyah radhiallahu 'anha memilih tanah."

Hadits ijarah terkait sewa aset berupa lahan pertanian dan perkebunan dapat dilihat pada riwayat Imam Muslim berikut (Naisaburi \& Al-Qusairi, 2006):

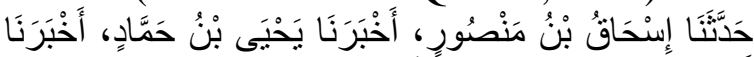

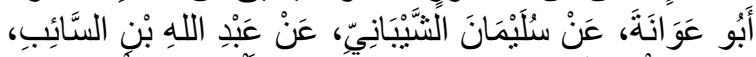

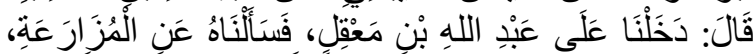

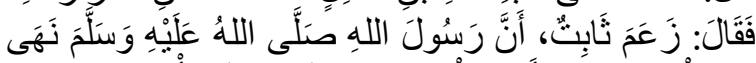

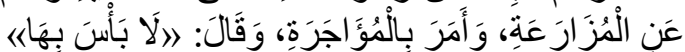

Artinya: Telah menceritakan kepada kami Ishaq bin Manshur telah mengabarkan kepada kami Yahya bin Hammad telah mengabarkan kepada kami Abu 'Awanah dari Sulaiman As Syaibani dari Abdullah bin As Sa'ib dia berkata; Saya menemui Abdullah bin Ma'qil dan bertanya mengenai praktek muzara'ah. Dia menjawab; Tsabit mengatakan bahwa Rasulullah shallallahu 'alaihi wasallam melarang praktek muzara'ah dan memerintahkan dengan cara muajarah (mengupah). Ma'qil melanjutkan; "Tidak mengapa jika dengan muajarah."

Hadits ijarah terkait sewa aset berupa lahan pertanian dan perkebunan diriwayatkan juga oleh Imam Bukhori (AlBukhari, 2000):

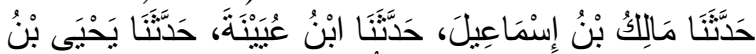

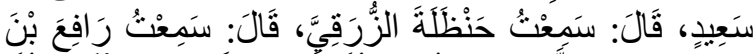

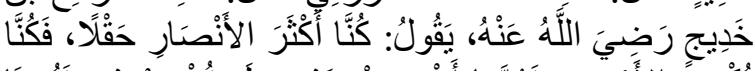

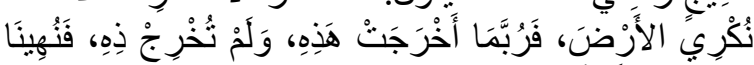

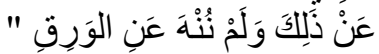

Artinya: Telah bercerita kepada kami Malik bin Isma'il telah bercerita kepada kami Ibnu 'Uyainah telah bercerita kepada kami Yahya bin Sa'id berkata aku mendengar Hanzholah Az Zuraqiy berkata aku mendengar Rofi' bin Khodij radliallahu 'anhu berkata: "Kami adalah orang Anshor yang paling banyak memiliki kebun dan kami memperkerjakan orang untuk menggarap ladang dan apabila ada hasilnya penggarapnya mendapatkan bagian dan bila tidak maka tidak dapat bagian. Kemudian kami dilarang mempraktekkan ini namun kami tidak dilarang bila memberi upah dengan uang."

Hadis ijarah terkait anjuran menyegerakan pembayarn upah buruh bisa dilihat pada riwayat Imam Bukhori (Naisaburi \& Al-Qusairi, 2006):

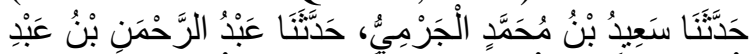

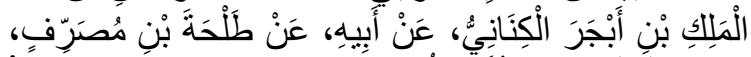

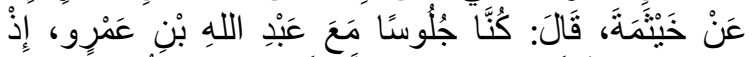

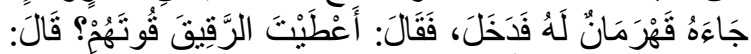

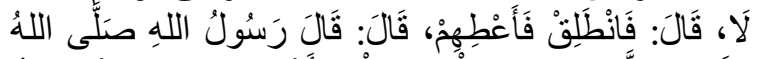

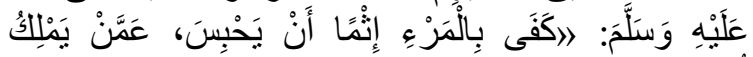
قُونَنَهُ

Artinya: Telah menceritakan kepada kami Sa'id bin Muhammad Al Jarmi Telah menceritakan kepada kami Abdurrahman bin Abdul Malik bin Abjar Al Kinani dari bapaknya dari Thalhah bin Musharrif dari Khaitsamah ia berkata; Ketika kami sedang duduk (belajar) bersama Abdullah bin Amr, tiba-tiba datang bendaharanya, lalu masuk dan Abdullah pun bertanya padanya, "Apakah kamu telah memberikan makan para hamba sahaya?" Sang bendahara menjawab, "Belum tuanku." Abdullah berkata, "Pergi, dan berilah makan mereka segera." Kemudian Ibnu Umar berkata; Rasulullah shallallahu 'alaihi wasallam bersabda: "Cukuplah seseorang itu dikatakan berdosa orang-orang yang menahan makan (upah dan sebagainya) orang yang menjadi tanggungannya."

Hadis larangan ijarah dalam perbuatan yang diharamkan atau terlarang diriwayatkan oleh Imam Bukhori (AlBukhari, 2000):

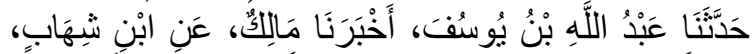

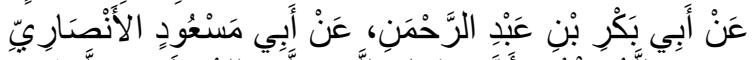

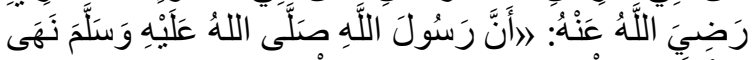

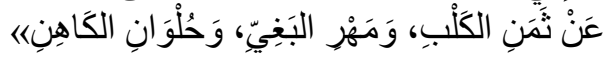

Artinya: Telah menceritakan kepada kami 'Abdullah bin Yusuf telah mengabarkan kepada kami Malik dari Ibnu Syihab dari Abu Bakar bin 'Abdurrahman dari Abu Mas'ud Al Anshariy radliallahu 'anhu bahwa Rasulullah shallallahu 'alaihi wasallam melarang uang hasil jual beli anjing, mahar seorang pezina dan upah bayaran dukun.

\section{Prinsip-Prinsip Hukum dalam Hadits Ijarah}


Salah satu landasan epistemologi dari bangunan hukum Islam itu adalah kemaslahatan. Maslahat sebagai fondasi hukum Islam diakui oleh Imam Malik, asy Syathibi, al Ghazali, 'Izzuddin ibn Abd. As Salam, dan Najmuddin At-Thufi (Sarifudin, 2019). Kemashlahatan akan tercipta manakala ada kepatuhan yang bersifat transendental dalam rangka memenuhi naluri kemanusian universal yang immanental (Madjid, 2018). Nilai-nilai dasar ini diformulasikan dalam prinsipprinsip hukum yang berlaku universal dalam rangka mewujudkan fleksibelitas hukum Islam, demikian halnya terhadap hukum ijarah yang kemudian bermetamorfosa menjadi Ijarah Muntahiyah Bittamlik (IMBT) dan Ijarah Maushufah Fi Dzimmah (IMFZ).

Ijarah sebagai salah satu jenis perjanjian dalam Islam banyak bersumber dari hadits Nabi Saw baik berupa hadits qauliyyah, fi'liyyah, taqririyah maupun hammiyah. Untuk dapat menggali hukum di dalam hadits perlu difahami prinsip-prinsip apa saja yang terkandung dalam hadits tersebut. Prinsip-prinsip hukum ini dapat dijadikan pedoman dalam menentukan status hukum suatu perbuatan atau peristiwa hukum baru yang bersifat furu'iyyah. Dalam hadits-hadits tentang ijarah di atas, setidaknya terdapat beberapa prinsip hukum yang dapat dijelaskan yaitu: prinsip ibahah (kebolehan) dan kebebasan berkontrak, prinsip keadilan, prinsip manfaat, prinsip tanggung jawab, prinsip konsensualisme, prinsip kesimbangan, dan prinsip amanah.

Prinsip ibahah dan kebebasan berkontrak mengandung makna bahwa segala sesuatu dalam bidang muamalah semisal ijarah hukumnya boleh selama tidak ada larangan syara'. Dalam praktek ijarah Nabi Saw maupun para sahabat melakukannya dalam berbagai jenis bentuk dan cara, sewa aset ataupun jasa, dengan batasan tidak boleh ada unsur riba, menunda pembayaran upah, dan gharar yang menimbulkan kezhaliman kepada pihak lain dalam akad. Prinsip Kebebasan berkontrak tergambar pada hadits dari Aisyah dan juga dari Anas bin Malik yang diriwayatkan alHakim: "Orang-orang muslim itu senantiasa mematuhi kepada syarat-syarat mereka pada apa yang disepakati dengan benar" (Naisaburi \& Al-Qusairi, 2006). Perjanjian apa saja dapat dibuat muslim dalam memenuhi kebutuhan hidupnya harus dipenuhi, inilah ciri dan sifat muslim yang ideal (Anwar, 2016).

Prinsip keadilan sangat fundamental dan merupakan tujuan dalam hukum Islam. Perintah berlaku adil dalam praktek ijarah dapat diselami diantaranya dari hadits tentang sewa lahan pertanian, bahwa harus berlaku adil kepada orang yang telah menggarapkan lahannya dengan memberikan hak upah atas pekerjaan sesuai dengan kuantitas dan kualitas kerjanya, dan jangan sampai kering keringatnya (menunda pembayaran upah).

Prinsip manfaat dalam ijarah sebagaimana kesepakatan jumhur ulama bahwa yang menjadi objek transaksi dalam ijarah adalah manfaat yang terkandung dari suatu benda ataupun jasa tanpa disertai pengalihan hak katas bendanya. Hal ini dapat dipahami dari hadits-hadits yang berbicara tentang sewa aset dan sewa jasa di atas dengan batasan bukan atas objek (benda/profesi) yang terlarang.

Prinsip tanggungjawab perlu diterapkan oleh para pihak yang terikat dalam akad ijarah. Setiap pihak yang mengikatkan diri harus melaksanakan tugas dan kewajiban masing-masing sesuai dengan kesepakatan dan akan menerima konsekwensinya dengan penuh tanggung jawab. Tanggungjawab berdampingan dengan hak para pihak yang tidak boleh dipisahkan.

Prinsip konsensualisme (kesepakatan) menjadi tanda dan kunci dalam suatu perjanjian untuk memastikan kapan mulai berlakunya akad sehingga dapat diperhitungkan batasan hak dan kewajiban para pihak, hingga apa saja konsekwensi hukumnya. Hal ini berlaku pula dalam akad ijarah yang tergambar dari hadits Nabi 
SAW riwayat Imam Muslim yang menceritakan upah bagi amil zakat yang dijelaskan kapan dan berapa lama dia bekerja maka upahnya pun dibayar karena merupakan haknya; dan hadits riwayat 'Abd ar-Razzaq, yang menjelaskan bahwa perlunya memberitahukan upah bagi orang yang dipekerjakan. Hal ini menunjukkan perlu adanya pembicaraan dan kesepakatan tentang upah sebelum pekerjaan itu dilaksanakan.

Prinsip keseimbangan perlu ada dalam ijarah dengan dasar transaksi muamalah yang mengandung unsur riba dilarang dalam Islam sebab terdapat ketidakseimbangan antara hak dan kewajiban dan penanggungan risiko diantara para pihak. Prinsip keseimbangan ini diharapkan menjadi barometer dalam bermuamalah.

Prinsip amanah dalam ijarah dimaksudkan agar para pihak memiliki itikad baik dalam bertransaksi dengan tidak melakukan eksploitasi ketidaktahuan pihak lainnya. Untuk itulah masing-masing pihak harus mengetahui hak dan kewajibanya sebagaimana dapat dipahami dari hadits Nabi SAW riwayat 'Abd ar-Razzaq dari Abu Hurairah dan dari Abu Sa'id berkata, "Jika kamu memperkerjakan orang, maka beritahukanlah upahnya".

\section{PEMBAHASAN DAN DISKUSI}

\section{Kedudukan Dewan Syariah Nasional Majelis Ulama Indonesia (DSN MUI)}

Pembentukan Dewan Syariah Nasional Majelis Ulama Indonesia (DSN-MUI) sejak tahun 1999 bertujuan untuk menyerap aspirasi umat Islam mengenai masalah perekonomian dan mendorong penerapan ajaran Islam dalam bidang perekonomian/keuangan yang dilaksanakan sesuai dengan tuntunan syariat Islam. Untuk mendorong penerapan ajaran Islam dalam kehidupan ekonomi dan keuangan, DSNMUI berkewajiban untuk selalu proaktif dalam menanggapi perkembangan masyarakat Indonesia yang dinamis dalam bidang ekonomi dan keuangan (DSN-MUI,
2021). Amanat ini diwujudkan salah satunya dengan menetapkan fatwa-fatwa tentang ekonomi dan keuangan syariah bagi umum dan Lembaga Keuangan Syariah untuk dijadikan sebagai dasar hukum operasional (Surat Keputusan Dewan Syariah Nasional MUI Nomor 02 Tahun 2000 tentang Pedoman Dasar DSN MUI Nomor 01 Tahun 2000 pada bagian tugas dan wewenang). Fatwa DSN MUI diharapkan dapat memperkecil perbedaan interpretasi syariah yang dapat berakibat pada perbedaan penetapan hukum suatu kasus yang berkenaan dengan ekonomi dan keuangan syariah khususnya di Indonesia (Nafis, 2011).

Sesuai dengan tugasnya, DSN MUI diberikan otoritas tidak hanya membentuk fatwa namun juga mengawasi pelaksanaan fatwa tersebut pada lembaga-lembaga keuangan syariah melalui Dewan Pengawas Syariah (DPS). Secara rinci ada beberapa otoritas yang dimiliki DSN MUI, yaitu (Nafis, 2011):

(1) Mengeluarkan fatwa yang mengikat bagi DPS di masing-amsing Lembaga Keuangan Syariah dan menjadi dasar tindakan hukum bagi pihak terkait;

(2) Mengeluarkan fatwa untuk kepentingan pembuatan ketentuan / peraturan institusi yang berhak seperti Kementerian Keuangan dan Bank Indonesia;

(3) Memberikan dukungan / rekomendasi dan/atau mencabut nama-nama yang akan ditetapkan sebagai DPS pada Lembaga Keuangan Syariah;

(4) Memberikan penjelasan suatu masalah yang berkaitan dengan ekonomi syariah termasuk otoritas moneter/lembaga keuangan dalam maupun luar negeri;

(5) Memberikan rekomendasi kepada Lembaga Keuangan Syariah untuk menghentikan penyimpangan dari fatwa yang telah dikeluarkan oleh DSN MUI. 


\section{Fatwa Syariah Nasional Majelis Ulama Indonesia (DSN MUI)}

Pembentukan fatwa DSN MUI menggunakan dasar-dasar dan prosedur yang diatur dalam Fatwa MUI Nomor: U596/MUI/X/1997 yang ditetapkan pada tanggal 2 Oktober 1997. Dasar-dasar dalam penetapan fatwa tercantum pada Pasal 2, yakni:

(1) Setiap keputusan fatwa harus berdasarkan atas Kitabullah dan Sunnah Rasul yang mu'tabarah serta tidak bertentangan dengan kemashlahatan umat;

(1) (2)Apabila tidak ditemukan dalil dalam Kitabullah dan Sunnah Rasul, maka keputusan hendaklah tidak bertentangan dengan ijma', qiyas yang mu'tabarah, dan dalil-dalil hukum lainnya sperti istihsan, mashlahah mursalah, dan saddu aldzariah;

(2) Tinjauan pendapat-pendapat para imam mazhab terdahulu hendaklah dilakukan sebelum pengambilan keputusan fatwa, baik yang berhubungan dengan dalil-dalil hukum maupun dalil yang digunakan dalam pendapat-pendapat tersebut;

(3) Mempertimbangkan pandangan tenaga ahli di bidang masalah yang akan diambil keputusan fatwanya (Mufid, 2018).

Apabila diperhatikan dalam ketentuan 1 Pasal 2 di atas bahwa penggunaan Sunnah Rasul disyaratkan yang mu'tabarah. Mu'tabarah berasal dari kata i'tibar yaitu suatu cara untuk mengidentifikasi hadits yang mutaba'ah (memiliki kesamaan dengan hadits lain baik lafadz atau maknanya, atau rawi sahabatnya) dan hadits syahid (ada kesamaan dengan hadits lain dari lafazd dan makna, namun berbeda rawi sahabatnya), sehingga dapat diketahui apakah satu hadits dengan hadits lain memiliki kesesuaian atau saling menguatkan baik dari rawi atau matan hadits tersebut (Al-Maliki, 2009). Hadits yang mu'tabarah dapat dipertanggungjawabkan sehingga dapat dijadikan hujjah dan sah untuk diamalkan (Mz, 2008).

DSN MUI telah menetapkan beberapa fatwa yang berkaitan dengan ijarah dan derivasinya yaitu:

(1) Fatwa Nomor 9/DSN-MUI/VI/2000 tentang Ijarah;

(2) Fatwa Nomor 27/DSNMUI/III/2002 tentang Al-Ijarah alMuntahiyah bi at-Tamlik;

(3) Fatwa Nomor 56/DSN-MUI/V/2007 tentang Ketentuan Review Ujrah pada Lembaga Keuangan Syariah;

(4) Fatwa Nomor 101/DSNMUI/X/2016 tentang Akad Al-Ijarah Al-Maushufah fi Al-Dzimmah;

(5) Fatwa Nomor 102/DSNMUI/X/2016 tentang Akad Al-Ijarah Al-Maushufah fi Al-Dzimmah Untuk Produk Pembiayaan Rumah (PPR)Inden;

(6) Fatwa Nomor 112/DSNMUI/IX/2017 tentang Akad Ijarah.

Fatwa-fatwa di atas sebagian besar menggunakan hadits yang sama sebagai salah satu jenis rujukannya, selain ayat-ayat Al-Qur'an, ijma', qiyas dan lainnya termasuk pendapat-pendapat ulama yang relevan. Hadits-hadits dimaksud sebagai landasan hukum ijarah pada umumnya yang kemudian dijadikan dalil utama dalam fatwa IMBT dan IMFZ. Berikut akan ditelaah penggunaan hadits pada fatwa ijarah, IMBT dan IMFZ.

\section{Telaah Hadits dalam Fatwa Ijarah, IMBT dan IMFZ}

Hadits yang digunakan sebagai dalil dalam penetapan Fatwa DSN MUI tentang Ijarah sebagaimana tercantum pula dalam Fatwa IMBT dan IMFZ terdiri dari beberapa hadits. Penulis lakukan takhrij al-hadits daripada kitab induknya, oleh karena itu hadits-hadits yang akan penulis tampilkan pada bagian ini akan dilengkapi dengan sanadnya sekaligus. 
Hadits Nabi Muahmmad Saw riwayat Ibnu Majah dari Ibnu Umar (Qazwini, 2016):

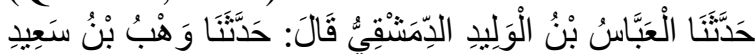

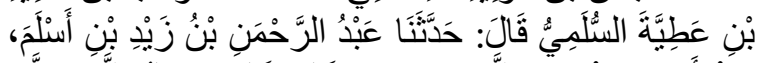

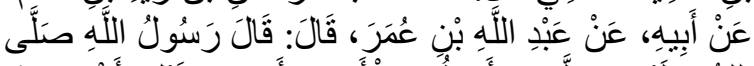

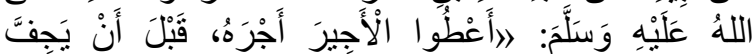
عَرَقُشُهُ

Artinya: Telah menceritakan kepada kami [Al Abbas bin Al Walid Ad Dimasyqi] berkata, telah menceritakan kepada kami [Wahb bin Sa'id bin Athiah As Salami] berkata, telah menceritakan kepada kami ['Abdurrahman bin Zaid bin Aslam] dari [Bapaknya] dari [Abdullah bin Umar] ia berkata, "Rasulullah shallallahu 'alaihi wasallam bersabda: "Berikanlah upah kepada pekerja sebelum kering keringatnya."

Dalam hadits ini Nabi SAW menekankan untuk menyegerakan membayar upah kepada orang yang dipekerjakan. Akibat hukum yang terjadi dari pelaksanakaan akad adalah munculnya hak dan kewajiban dari kedua belah pihak yang berakad. Kewajiban dari orang yang mempekerjakan untuk menyegerakan membayar upah berkorelasi dengan hak dari pekerja untuk menerima upah atas pekerjaan yang dilaksanakan. Perbuatan menunda pembayaran upah terhadap pekerja yang berhak atas upahnya secara sengaja dan tanpa uzur apapun adalah salah satu bentuk kezhaliman, termasuk perbuatan yang berdosa apalagi sampai tidak membayarnya

Hadits riwayat 'Abdur Razzaq dari Abu Hurairah dan Abu Sa'id al-Khudri, sebagaimana diriwayatkan pula An-Nasai dari Abu Sa'id (Ash-Shan'ani, 1982):

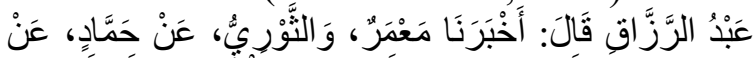

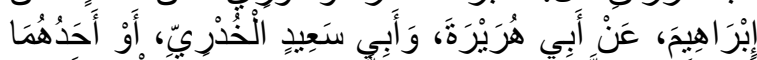

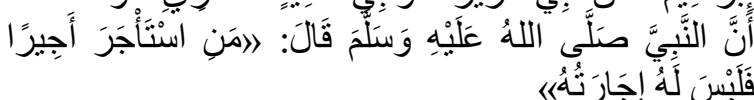

Artinya: Telah mengabarkan kepada kami Ma'mar dan ats-Tsauri; dari Hammad; dari Ibrahim, dari Abu Hurairah dan Abu Sa'id al-Khudri, atau salah satu daripada keduanya bahwa Nabi saw. bersabda: "Barang siapa mempekerjakan pekerja, beritahukanlah upahnya." Abu Zar'ah berkata hadits ini shahih mauquf pada Abu Sa'id (Az-Zuhaili, 2011).

Hadits Nabi riwayat Imam anNasa'i (An-Nasa'i, 1986)

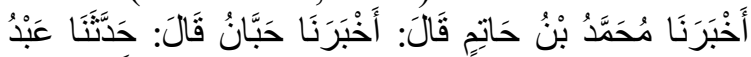

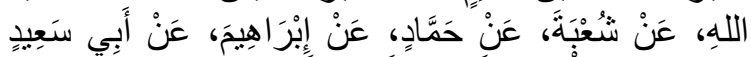

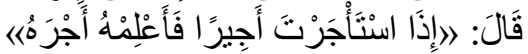

Artinya: Telah mengabarkan kepada kami [Muhammad bin Hatim] berkata; telah memberitakan kepada kami [Hibban] berkata; telah memberitakan kepada kami [Abdullah] dari [Syu'bah] dari [Hammad] dari [Ibrahim] dari [Abu Sa'id] berkata, "Jika kamu memperkerjakan orang, maka beritahukanlah upahnya." (HR. an-Nasa'i).

Hadits Nabi riwayat Imam Abu Daud dari Sa`d Ibn Abi Waqqash (Sijistânî, 1969):

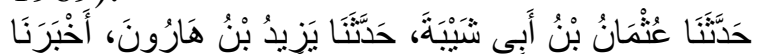

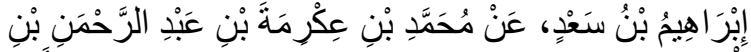

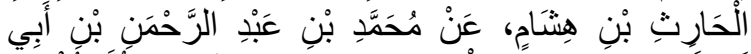

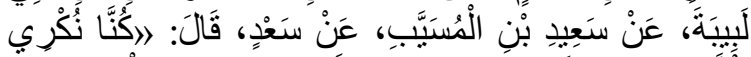

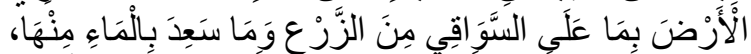

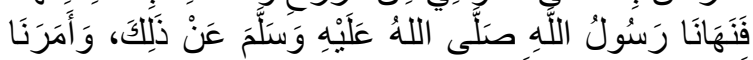

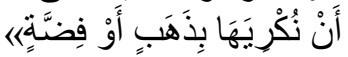

Artinya: Telah menceritakan kepada kami [Utsman bin Abu Syaibah?], telah menceritakan kepada kami [Yazid bin Harun] telah mengabarkan kepada kami [Ibrahim bin Sa'd] dari [Muhammad bin Ikrimah bin Abdurrahman bin Al Harits bin Hisyam] dari [Muhammad bin Abdurrahman bin Abu Labibah] dari [Sa'id bin Al Musayyab], dari [Sa'd] ia berkata; dahulu kami menyewakan tanah dengan upah tanaman yang tumbuh di atas sungaisungai kecil serta sungai-sungai yang mengalir airnya tersebut. Kemudian Rasulullah shallallahu 'alaihi wasallam melarang kami dari hal tersebut dan beliau memerintahkan kami untuk menyewakannya dengan upah emas atau perak.

Hadits Nabi riwayat Imam atTirmidzi dan Ibnu Majah dari 'Amr bin 'Auf al-Muzani (At-Tirmidzi, 1998):

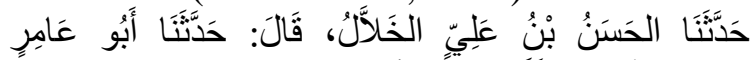

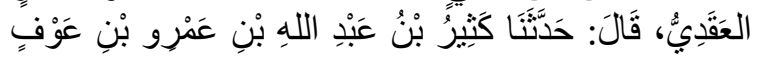




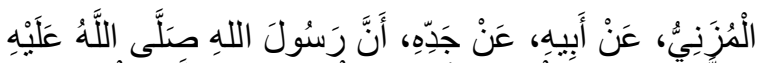

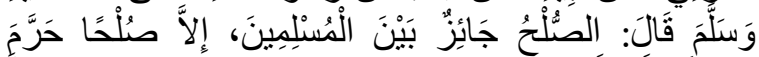

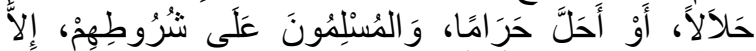

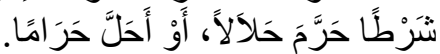

Artinya: Telah menceritakan kepada kami [Al Hasan bin Ali Al Khallal], telah menceritakan kepada kami [Abu Amir Al 'Aqadi], telah menceritakan kepada kami [Katsir bin Abdullah bin Amru bin 'Auf Al Muzani] dari [ayahnya] dari [kakeknya] bahwa Rasulullah shallallahu 'alaihi wasallam bersabda: "perdamaian diperbolehkan di antara kaum muslimin kecuali perdamaian yang mengharamkan yang halal atau menghalalkan yang haram. Dan kaum muslimin boleh menentukan syarat kecuali syarat yang mengharamkan yang halal atau menghalalkan yang haram."

\section{Telaah Hadits Multiakad dalam Fatwa IMBT dan IMFZ disertai Ketentuan Hukumnya}

Adapun hadits yang sama dalam Fatwa DSN nomor 27/DSN-MUI/III/2002 tentang AlIjarah Al-Muntahiyah bi Al-Tamlik, Nomor 101/DSN-MUI/X/2016 tentang Al-Ijarah Al-Maushufah fi Al-Dzimmah dan 102/DSN-MUI/X/2016 tentang Al-Ijarah Al-Maushufah fi Al-Dzimmah untuk Produk Pembiayaan Pemilikan Rumah (PPR) yang menjadi dalil memperkuat legitimasi akad khususnya IMBT dan IMFZ yang berkaitan dengan multiakad adalah riwayat Ahmad dari Ibnu Mas'ud (Asy-Syaibani, 2001):

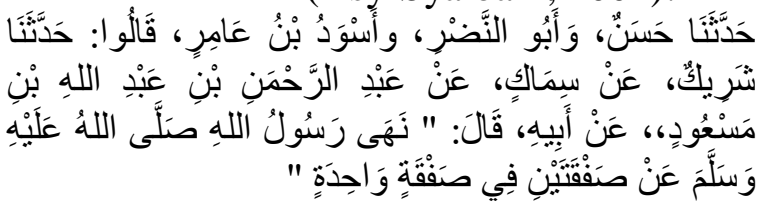

Artinya: Telah menceritakan kepada kami Hasan dan Abu Nadhr dan Aswad bin Amir mereka berkata; Telah menceritakan kepada kami Syarik dari Simak dari Abdurrahman bin Abdullah bin Mas'ud radhiallahu 'anhuma dari ayahnya berkata; Rasulullah shallallahu 'alaihi wasallam melarang dua akad dalam satu transaksi.

Hadits ini mengandung hukum larangan menggabungkan dua akad dalam satu transaksi (murakkab) sebab dikhawatirkan akan mengandung unsur riba. Penjelasan ini dapat ditemukan pada Hadits dari Ibnu Mas'ud dalam Shahih Ibnu Hibban berikut (At-Tamîmî, 2001):

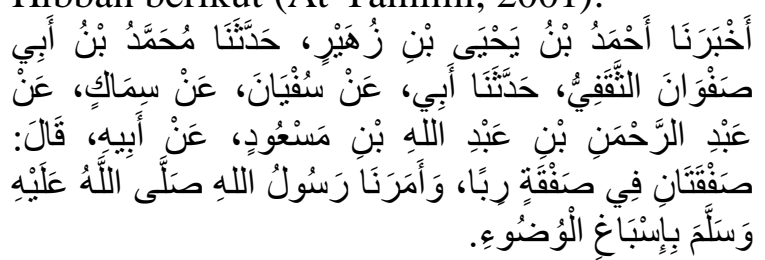

Artinya: Ahmad bin Yahya bin Zuhair mengabarkan kepada kami, Muhammad bin Abu Shafwan Ats-Tsaqafi menceritakan kepada kami, ayahku menceritakan kepadaku, dari Simak, dari Abdurrahman bin Abdullah bin Mas'ud, dari ayahnya, ia berkata, "Adanya dua akad di dalam satu akad jual beli adalah riba. Dan Rasulullah shallallahu 'alaihi wa sallam memerintahkan kepada kami untuk menyempurnakan wudhu."

Hadits lainnya yang menerangkan tentang multiakad (Asy-Syaibani, 2001):

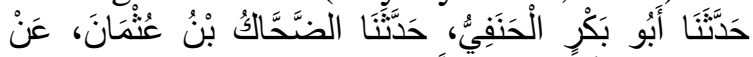

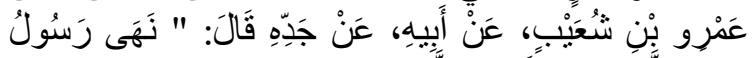

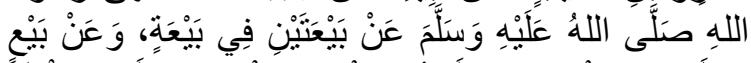

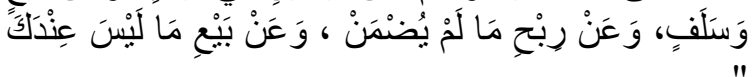

Artinya: Telah menceritakan kepada kami [Abu Bakar Al Hanafi] telah menceritakan kepada kami [Adl-dlahhak bin Utsman] dari ['Amru bin Syu'aib] dari [bapaknya] dari [kakeknya] dia berkata; Rasulullah Shallallahu 'alaihi wa Salam melarang dua jual beli dalam satu jual beli, jual beli dengan pinjaman, keuntungan dari barang yang tidak dapat dijamin, dan menjual yang tidak ada padamu."

Pelarangan dua akad dalam satu transaksi dengan dua jual beli dalam satu jual beli(بَيْعَتَنْنِ فِي بَيْعَةِ telah disepakati oleh para fuqaha, karena didalamnya selain dapat menjerumuskan kepada riba, juga dapat memunculkan unsur ketidakjelasan (gharar). Namun ada perbedaan pendapat mengenai pengaplikasian bentuk akadnya, sebab adanya perbedaan dalam menafsirkan makna dua transaksi jual beli dalam satu jual beli. Imam Syafi'i menyebutkan ada dua penafsiran terkait masalah ini, yaitu; 
Pertama, seseorang mengatakan, 'Saya jual barang ini kepadamu dengan harga 2000 secara kredit atau dengan harga 1000 secara tunai maka mana saja yang kamu mau kamu boleh pilih. Namun, jual beli dianggap lazim pada salah satu pilihan sehingga jual beli ini batal, karena terjadi pengaburan dan penggantungan jual beli. Kedua, seseorang mengatakan, 'Saya jual kepadamu rumahku dengan syarat kamu jual kepadaku kudamu. "Alasan pelarangan pada transaksi pertama, karena transaksi itu mengandung gharar yang disebabkan oleh ketidakjelasan mengenai jumlah harga, dimana pembeli tidak tahu secara pasti pada saat transaksi berapa jumlah harga barang, apakah misalnya 2000 atau 1000. Sedangkan alasan pelarangan transaksi kedua, mencegah untuk memanfaatkan kebutuhan orang lain. Ini terjadi pada saat orang terpaksa membeli sebuah barang maka syarat yang diberikan penjual kepada pembeli ketika membeli barang darinya termasuk bentuk eksploitasi yang bisa menyebabkan hilangnya unsur kerelaan dalam jual beli. Di samping itu, transaksi kedua juga mengandung unsur gharar, dimana penjual tidak mengetahui apakah jual beli kedua akan terjadi ataukah tidak (Az-Zuhaili, 2011).

Hanafi berpendapat bahwa jual beli ini fasid karena harga barang tidak jelas dan adanya penggantungan serta ketidakjelasan, dimana harga barang tidak tentu, apakah dibayar tunai atau kredit. Jika harga barang ditetapkan dan diterima pada salah satu pilihan, maka transaksi menjadi sah. Sedangkan Syafi'i dan Hanbali berpendapat bahwa transaksi jual beli ini batal karena dianggap mengandung gharar dengan sebab adanya ketidakjelasan di dalamnya. Karena penjual tidak memutuskan bentuk jual beli yang dia lakukan. Adapun Malik berpendapat bahwa jual beli ini sah dan dianggap sama dengan jual beli yang memberi pilihan kepada pihak pembeli. Karena itu, transaksi berlaku pada salah satu bentuk jual beli yang dipilih, dimana bisa dikatakan bahwa terjadi di antara kedua belah pihak seperti apa yang disepakati dalam transaksi, seperti halnya seorang pembeli berkata, "Saya beli barang ini dengan harga sekian kredit", lalu penjual menjawabnya,'Ambil!" atau, "Saya rela", atau ungkapan semacamnya, maka transaksi telah sempurna (Az-Zuhaili, 2011).

Jual beli seperti di atas dilarang manakala sebuah akad yang mengandung dua jual beli, salah satu dari jual beli itu dinyatakan mengikat (lâzim) sebelum para pihak berpisah namun tidak ditentukan jual beli manakah yang diakadkan dan mengikat tersebut. 'Illat larangan bentuk jual beli ini adalah ketidakpastian yang timbul dari ketidakjelasan nilai harga (Maulana, 2011).

Ketidakjelasan terjadi pada transaksi jual beli ini, sebenarnya dikarenakan dari dua harga yang ditawarkan tidak dipilih salah satunya, melainkan berakad atas dua harga tersebut dengan menyepakati jual beli yang dilakukan atas dua bentuk jual beli, sehingga ada ketidakjelasan atas transaksi yang dilakukan melalui ketidakjelasan harga apakah menggunakan harga jual beli tunai senilai 1000 ataukah jual beli kredit senilai 2000. Karena itu transaksi ini menjadi dua jual beli dalam satu jual beli. Berbeda halnya jika setelah ditawarkan dua harga atas dua bentuk jual beli tadi oleh pembeli, selanjutnya pembeli memilih salah satu dari keduanya baik jual beli tunainya ataupun jual beli kreditnya, maka tidak terjadi dua jual beli atas satu jual beli, karena telah dipilih dan disepakati satu bentuk akad jual beli saja.

Multiakad atau hybrid contract dalam literatur fikih muamalah kontemporer dikenal dengan istilah al-uqud al-murakkabah. Sebagaimana dijelaskan 'Abdullah al 'Imrânî dalam al-'Uqûd alMâliyyah al-Murakkabah: Dirâsah Fiqhiyyah Ta'shîliyyah wa Tathbîqiyyah, bahwa yang dimaksud dengan akad murakkab adalah himpunan beberapa akad kebendaan yang dikandung oleh sebuah akad, baik secara gabungan maupun secara timbal-balik, sehingga seluruh hak dan kewajiban yang ditimbulkannya dipandang sebagai akibat hukum dari satu akad (Al- 
Imrani, 2006). Sedangkan Nazîh Hammâd dalam al- 'Uqûd al-Murakkabah fi al-Fiqh al-Islâmî mendefinisikan akad murakkab sebagai kesepakatan dua pihak untuk melaksanakan suatu akad yang mengandung dua akad atau lebih, seperti jual beli dengan sewa menyewa, hibah, wakâlah, qardh, muzâra'ah, sharf, syirkah, mudhârabah, dst., sehingga semua akibat hukum akadakad yang terhimpun tersebut, serta semua hak dan kewajiban yang ditimbulkannya dipandang sebagai satu kesatuan yang tidak dapat dipisah-pisahkan, sebagaimana akibat hukum dari satu akad (Hammad, 2005).

Para ulama membolehkan praktik multiakad dengan beberapa kriteria atau batasan dibolehkannya, jika batasan ini dilanggar atau tidak sesuai kriteria yang telah ditetapkan tersebut, maka multiakad tersebut status hukumnya adalah terlarang untuk dilakukan. Kriteria ini menjadi syarat atas dilaksanakannya multiakad yang legal secara syar'i. Kriteria kebolehan multiakad yang dirumuskan oleh para ulama secara umum yakni:

(1) Bukan multiakad yang dilarang oleh nash agama;

(2) Bukan multiakad sebagai hilah ribawiyah;

(3) Bukan multiakad yang menyebabkan jatuh ke riba; dan

(4) Bukan multiakad yang termasuk akad-akadnya tidak boleh digabung.

Multiakad yang dilarang oleh nash agama seperti multiakad dalam jual beli (bai') dengan pinjaman, dua akad jual beli dalam satu jual beli dan dua akad dalam satu transaksi, sebagaimana disebutkan hadits riwayat Imam Ahmad (Asy-Syaibani, 2001):

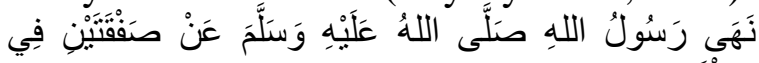
صَفْقَة وَاحِدَةٍ

Artinya: Rasulullah shallallahu 'alaihi wasallam melarang dua akad dalam satu transaksi.

Kemudian ada juga hadits riwayat Imam Malik dan Imam Ahmad (Al-Madani, 1985; Asy-Syaibani, 2001):

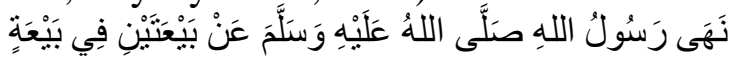

Artinya: Rasulullah Shallallahu 'alaihi wa Salam melarang dua jual beli dalam satu jual beli.

Berikutnya hadits riwayat Imam Malik (Al-Madani, 1985):

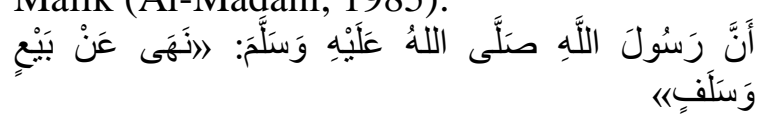

Artinya: Sesungguhnya Rasulullah Shallallahu 'alaihi wa Salam melarang jual beli dengan pinjaman.

Multiakad yang menjadi hilah ribawiyah (rekayasa hukum praktik riba) dapat terjadi pada transaksi jual beli inah. Setiap multiakad yang mengantarkan pada yang haram, seperti riba, hukumnya haram, meskipun akad akad yang membangunnya adalah boleh. Penghimpunan beberapa akad yang hukum asalnya boleh namun membawanya pada yang dilarang menyebabkan hukumnya menjadi dilarang. Contohnya seperti menggabungkan akad qardh dengan akad mu'awadhah / akad tijarah / akad komersial. Multiakad yang termasuk akad-akadnya tidak boleh digabung (karakter akadnya) terdiri atas akad-akad yang akibat hukumnya saling bertolak belakang atau berlawanan (Maulana, 2011). Contohnya adalah memberikan barang kepada seseorang dengan syarat menyewakannya kepada pihak pemberi tersebut, menggabungkan antara akad mudharabah dan qardh, menggabungkan antara akad sharf dan ju'alah, menggabungkan antara akad ijarah dan jual beli.

\section{Telaah Hadits Khusus dalam Fatwa IMFZ}

Untuk menunjang eksistensi dan legalitas skema akad IMFZ, dalam fatwa DSN MUI ditambahkan hadits tentang prinsip dasar jual beli dan akad salam, serta dua hadits tentang pembayaran utang.

Fatwa IMFZ mengutip hadits tentang prinsip dasar jual beli diriwayatkan Imam Baihaqi dan Ibnu Majah dinilai shahih oleh Ibnu Hibban (Al-Baihaqi, 1994; At-Tamîmî, 2001; Qazwini, 2016): 


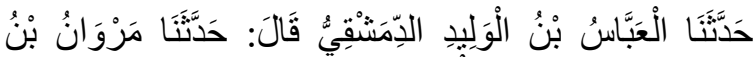

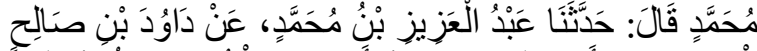

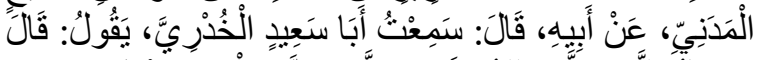

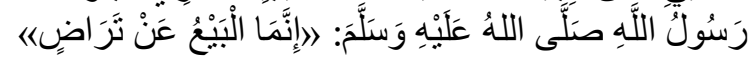
Artinya: Telah menceritakan kepada kami al Abbas bin al Walid ad Dimasyqi berkata, telah menceritakan kepada kami Marwan bin Muhammad berkata, telah menceritakan kepada kami Abdul Aziz bin Muhammad dari Dawud bin Shalih al Madini dari Bapaknya berkata; aku mendengar Abu Sa'id al Khudri, ia berkata, "Rasulullah shallallahu 'alaihi wasallam bersabda: "Sesungguhnya jual beli itu berlaku dengan saling ridha (suka sama suka)."

Fatwa IMFZ juga mengambil dasar hadits tentang jual beli salam riwayat Imam Bukhori (Al-Bukhari, 2000):

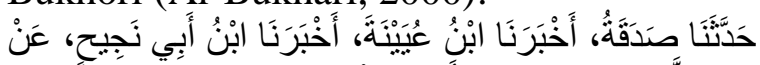

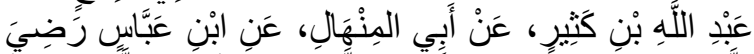

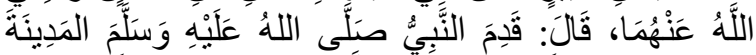

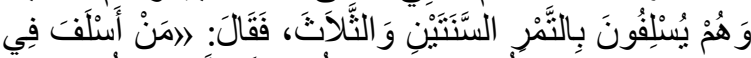

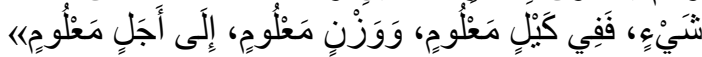
Telah menceritakan kepada kami Shadaqah telah mengabarkan kepada kami Ibnu 'Uyainah telah mengabarkan kepada kami Ibnu Abi Najih dari 'Abdullah bin Katsir dari Abu Al Minhal dari Ibnu 'Abbas radhiallahu 'anhuma berkata: Ketika Rasulullah shallallahu 'alaihi wasallam tiba di Madinah, mereka (penduduk Madinah) mempraktekan jual beli buah-buahan dengan sistim salaf, yaitu membayar dimuka dan diterima barangnya setelah kurun waktu dua atau tiga tahun kemudian, Maka Beliau bersabda: "Barang siapa melakukan salaf (salam), hendaknya ia melakukan dengan takaran yang jelas dan timbangan yang jelas, untuk jangka waktu yang diketahui." (HR. Bukhari).

Hadits berikutnya yang dicantumkan dalam Fatwa IMFZ menjelaskan tentang pembayaran utang yang diriwatakan Bukhari, Muslim, Ibnu Majah dan Abu Daud (Al-Bukhari, 2000; Naisaburi \& AlQusairi, 2006; Qazwini, 2016; Sijistânî, 1969):

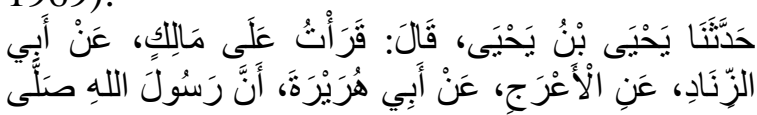

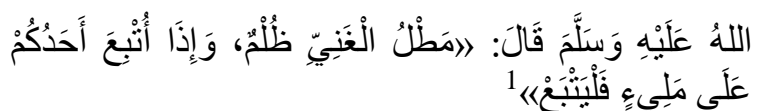

Telah menceritakan kepada kami Yahya bin Yahya dia berkata; saya baca di hadapan Malik; dari Abu Zinnad dari Al A'raj dari Abu Hurairah, bahwa Rasulullah shallallahu 'alaihi wasallam bersabda:

"Menunda-nunda pembayaran utang yang dilakukan oleh orang mampu adalah suatu kezaliman. Maka, jika seseorang di antara kamu dialihkan hak penagihan piutangnya (dihawalahkan) kepada pihak yang mampu, terimalah."

Hadits berikutnya yang dicantumkan dalam Fatwa IMFZ diriwayatkan oleh Imam Ibnu Majah, Imam an-Nasa'i, Abu Dawud dan Imam Ahmad menjelaskan tentang larangan menunda pembayaran utang (An-Nasa'i, 1986; Asy-Syaibani, 2001; Qazwini, 2016; Sijistânî, 1969):

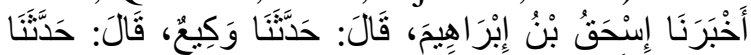

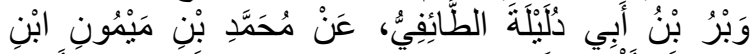

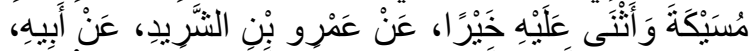

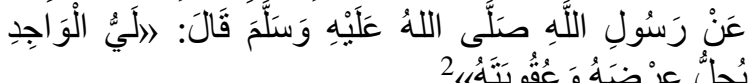

Telah mengabarkan kepada kami Ishaq bin Ibrahim telah menceritakan kepada kami Waki' telah menceritakan kepada kami Wabr bin Abu Dulailah Ath Thaify dari Muhammad bin Maimun bin Musaikah dan dia memujinya dengan kebaikan dari 'Amru bin Asy Syarid dari ayahnya dari Rasulullah shallallahu 'alaihi wasallam, beliau bersabda: "Menunda-nunda (pembayaran) yang dilakukan oleh orang mampu, menghalalkan harga diri dan pemberian sanksi kepadanya."

\section{Pendapat Para Ulama terhadap IMFZ}

Ijarah al Maushufah fi al Dzimmah (IMFZ) atau yang biasa dikenal dengan ijarah inden ini merupakan derivasi akad ijarah kontemporer yang kedudukan dan sifatnya memiliki hubungan erat dengan jual beli salam. Sesuai dengan namanya, sewa-

\footnotetext{
Muslim

1 Sanad hadits diambil dari riwayat Imam

${ }^{2}$ Sanad hadits diambil dari riwayat Imam anNasa'i.
} 
menyewa atas manfaat suatu barang ('ain) atau jasa ('amal) pada saat akad ini diucapkan/dilakukan hanya disebutkan sifatsifat, kuantitas dan kualitasnya (spesifikasi). Untuk itu, hadits-hadits yang digunakan sebagai rujukannya terdiri atas dalil ijarah dan salam. Akad IMFZ ini mulai dikembangkan lembaga keuangan syariah khususnya setelah terbitnya Fatwa DSN Nomor 101/DSN-MUI/X/2016 tentang Akad Al Ijarah al Mausufah fi Al Dzimmah.

Akad salam yang disertakan dalam IMFZ ini didalilkan pada kebolehan salam berdasarkan hadits riwayat Bukhari dari Ibnu Abbas ra. Berdasarkan Hadits di atas, praktek jual beli dengan cara salaf/salam diperbolehkan dalam Islam, dengan ketentuan mendahulukan pembayaran harga di majelis akad sebelum barang diterima. Barang yang dipesan harus jelas baik jumlah, jenis, ciri-ciri, ukuran, dan waktunya (As-Sa'di, 2012). Syarat kejelasan dalam kualitas, kuantitas dan waktu penyerahan pada jual beli salam inipun disebutkan oleh Imam an Nawawi dan Ibnu Hajar al Asqalani ketika mensyarah hadits tentang jual beli salam (Al-Asqalani, 2005; An-Nawawi, 2010) Demikian pula dalam Fatwa IMFZ Nomor 101 dan 102 dijelaskan akad al-Ijarah al-Maushufah fi al-Dzimmah adalah akad sewa menyewa atas manfaat suatu barang (manfaat 'ain) dan/atau jasa ('amal) yang pada saat akad hanya disebutkan sifat-sifat dan spesifikasinya (kuantitas dan kualitas).

Mengingat cukup kompleksnya hubungan hukum yang ada dalam akad IMFZ ini dengan jual beli salam, maka DSN MUI nampak sangat berhati-hati dalam menetapkan fatwanya. Hal ini dapat diamati dari pengutipan jumhur ulama klasik (Malikiyah, Syafi'iyyah, dan Hanabillah), selain Hanafiyyah, dan ulama kontemporer yang dicantumkan sangat detail, tidak sama halnya dengan fatwa ijarah dan IMBT. Ulama klasik yang dikutip pendapatnya adalah Malikiyah dan Syafi'iyyah yang berpendapat bahwa pembayaran ujrah dalam akad IMFZ harus di awal pada saat akad (majelis akad), sama halnya seperti membayar harga (staman) dalam akad salam dan agar terhindar dari jual beli piutang dengan piutang. Sementara ulama Hanabillah memiliki dua pendapat, yaitu: pertama, ujrah IMFZ dapat dibayar pada akhir akad seperti halnya diqiyaskan pada akad ijarah atas barang sesuai kesepakatan para pihak. Kedua, ujrah harus dibayar di awal dalam majelis akad dengan qiyas pembayaran (tsaman) dalam akad jual-beli salam. Pendapat ulama klasik ini dipertegas dengan pendapat Badr al-Hasan al-Qasimi dan Ahmad Muhammad Mahmud Nashar yang dikutip pula dalam fatwa IMFZ tersebut. Selanjutnya ditambahkan dalam kitab Al-Ma'ayir al-Syar'iyyah Nomor 9 tentang parameter (dhawabith) al-Ijarah wa al-Ijarah al-Muntahiyyah bi al-Tamlik, bahwa ada hak opsi bagi penyewa untuk menolak dan meminta gantinya yang sesuai dengan kriteria yang disepakati pada saat akad jika selama ijab-qabul yang dilakukan tidak menggunakan lafadz salam atau salaf (Fatwa DSN MUI Nomor 101 dan 102).

Adapun pendapat ulama kontemporer yang digunakan dalam fatwa IMFZ untuk mempertegas ketentuan waktu pembayaran ujrah, yaitu:

(1) Muhammad Sa'id al-Buthi dalam paper yang berjudul "al-Ijarah al-Maushufah fi al-Dzimmah" yang disampaikan dalam Muktamar Keuangan Bank di Bahrain pada tahun 2007, berpendapat bahwa ujrah dalam akad al-Ijarah alMaushufah fi al-Dzimmah wajib dibayar di awal pada majelis akad sebagaimana dalam akad jual-beli salam;

(2) Abd al-Sattar Abu Ghuddah berpendapat bahwa pembayaran ujrah dalam akad al-Ijarah al-Maushufah fi al-Dzimmah boleh diakhirkan meskipun dalam perjanjiannya menggunakan kata jual-beli salam

(3) Nazih Hammad berpendapat bahwa pembayaran ujrah dalam akad al-Ijarah al-Maushufah fi al-Dzimmah boleh 
diakhirkan apabila menggunakan lafadz ijarah, bukan lafadz salam;

(4) Ali al-Qaradaghi dalam paper yang berjudul "al-Ijarah 'ala Manafi' alAsykhash" yang disampaikan dalam acara Majelis Fatwa Eropa tahun 2008 di Paris (Perancis), membolehkan pengakhiran pembayaran ujrah dalam akad akad al-Ijarah al-Maushufah fi alDzimmah (baca: ujrah tidak mesti dibayar di muka atau dibayar pada saat akad) apabila perjanjiannya menggunakan kata ijarah; dan wajib mendahulukan pembayaran ujrah apabila menggunakan lafadz salam

\section{KESIMPULAN}

Fatwa DSN-MUI tentang Ijarah, Ijarah Muntahiyah Bittamlik dan ijarah Maushufah fi Dzimmah telah mengakomodir haditshadits ekonomi syariah yang menjadi landasan hukum terkait legalitas ijarah dan bentuk pengembangannya pada Ijarah Muntahiyah Bittamlik dan ijarah Maushufah $f i$ Dzimmah. Hadits-hadits yang menjadi muatan fatwa DSN-MUI tentang Ijarah, Ijarah Muntahiyah Bittamlik dan ijarah Maushufah fi Dzimmah dalam kajian penulis adalah relevan dengan objek kajian fatwa dan fiqh al-hadits-nya memang memiliki korelasi dengan objek kajian fatwa baik itu korelasi secara eksplisit maupun korelasi secara implisit, karena ada hadits-hadits yang memang bersifat khusus sehingga berkorelasi secara langsung seperti haditshadits yang menunjukkan eksistensi akad ijarah, adapula hadits-hadits yang bersifat umum seperti hadits tentang prinsip dasar jual beli yakni prinsip 'antaradhin (saling ridha), hadits perikatan, hadits jual beli salam, hadits multiakad dan hadits larangan menunda pembayaran utang.

\section{DAFTAR PUSTAKA}

Al-Asqalani, I. H. (2005). Fathul Bâri. Jakarta: Pustaka Azzam.

Al-Baihaqi, A. I. H. (1994). As-Sunan alKubrâ. Mekkah: Maktabah Dar al-Baz.

Al-Bukhari, A. A. M. bin I. (2000). Shahih
Bukhari. Beirut: Darul Kutub Ilmiyah. Al-Imrani, A. (2006). al-Uqud al-Maliyah al-Murakkabah. Dar Kunuz Ishbiliyya. Al-Madani, M. bin A. bin M. bin Â. al A. (1985). Al-Muwaththa'. Beirut: Dâr Ihyâ' at-Turâts al- Ârab.

Al-Maliki, M. A. (2009). Ilmu Ushul Hadits. Yogyakarta: Pustaka Pelajar.

An-Nasa'i. (1986). Sunan an-Nasa'i. Halb: Maktab al-Mathbû'ât al-Islamiyyah.

An-Nawawi, A. Z. M. (2010). Syarah Shahih Muslim. Jakarta: Darus Sunnah.

Anwar, S. (2016). Hukum Perjanjian Syariah: Studi Tentang Teori Akad Dalam Fikih Muamalat. Jakarta: Raja Grafindo Persada.

As-Sa'di, A. bin N. (2012). Syarah Umdatul Ahkam. Jakarta: Darus Sunnah.

Ash-Shan'ani, A. (1982). Mushannaf. Beirut: al Maktab al-Islami.

Asy-Syaibani, A. A. A. bin M. bin $\mathrm{H}$. (2001). Musnad Ahmad. Beirut: Muassasah ar-Risâlah.

At-Tamîmî, M. bin H. bin A. bin H. bin M. bin M. (2001). Shahîh Ibnu Hibban. Beirut: Muassasah ar-Risâlah.

At-Tirmidzi, A. I. M. bin I. bin S. (1998). Sunan At-Tirmidzi. Beirut: Dar alGharb al-Islami.

Az-Zuhaili, W. (2011). Fiqih Islam Wa Adillatuhu. Jakarta: Gema Insani Press.

DSN-MUI. (2021). DSN-MUI - Dewan Syariah Nasional-Majelis Ulama Indonesia.

Dzubyan, D. M. (2019). Analisis akad ijarah muntahiya bittamlik (imbt) dalam perspektif hukum islam dan hukum positif di indonesia. Amwaluna: Jurnal Ekonomi Dan Keuangan Syariah, 3(2), 181-196.

Fauzi, N. A. F. (2017). Fatwa di Indonesia: Perubahan Sosial, Perkembangan, dan Keberagaman. Jurnal Hukum Novelty, 8(1), 107-121.

Fuadi, N. F. Z. (2019). Implementasi Akad Al-Ijarah Al-Maushufah Fi Al- 
Dzimmah Sebagai Alternatif Pembiayaan Di Lembaga Keuangan Syariah Indonesia. Indonesian Journal of Islamic Literature and Muslim Society, 4(2).

Habibaty, D. M. (2018). eranan Fatwa Dewan Syariah Nasional-Majelis Ulama Indonesia-Terhadap Hukum Positif Indonesia. Jurnal Legislasi Indonesia, 14(4), 447-453.

Hammad, N. (2005). al-'Uqûd alMurakkabah fî̀ al-Fiqh al-Islâmî. Damaskus: Dar Al-Qalam.

Iskandar, A., \& Aqbar, K. (2019). Reposisi Praktik Ekonomi Islam: Studi Kritis Praktik Ekonomi Islam di Indonesia. NUKHBATUL'ULUM: Jurnal Bidang Kajian Islam, 5(1), 39-53.

Madjid, S. S. (2018). Prinsip-Prinsip (AsasAsas) Muamalah. J-HES: Jurnal Hukum Ekonomi Syariah, 2(1).

Maulana, H. (2011). Multiakad Dalam Transaksi Syariah Kontemporer Pada Lembaga Keuangan Syariah Di Indonesia. Al-Iqtishad: Jurnal Ilmu Ekonomi Syariah, 3(1).

Mufid, M. (2018). Ushul Fiqh Ekonomi dan Keuangan Kontemporer: Dari Teori ke Aplikasi. Jakarta: Kencana.

Mz, S. (2008). Al-Kutub Al-Mu'tabarah: Kajian atas Sumber Rujukan dalam Beristinbat Menurut NU, Muhammadiyah, dan Persis. AsySyir'ah: Jurnal Ilmu Syari'ah Dan Hukum, 42(1), 37-54.

Nafis, M. C. (2011). Teori Hukum Ekonomi Syariah. Jakarta: UI Press.

Naisaburi, M. bin al-H. al, \& Al-Qusairi, I. M. I. H. (2006). Shahih Muslim. Beirut: Dar Ihya Al-Turats Arabi.

Nur, S. (2017). Jenis dan Langkah Penelitian Hadis. NUKHBATUL'ULUM: Jurnal Bidang Kajian Islam, 3(1), 19-25.

Qazwini, A. A. M. bin Y. Al. (2016). Sunan Ibnu Majah. Depok: Gema Insani Press.

Saparullah, A. (2021). Urgensi Kedudukan Hadist Terhadap Al-Qur'an: Bayan Al-
Ta'kid, Bayan Al-Tafsir, dan Bayan Al-Tasyri. Jurnal Tana Mana, 2(1), 57-64.

Sarifudin, S. (2019). Hukum Islam Progresif: Tawaran Teori Maslahat AtThufi sebagai Epistemologi untuk Pembangunan Hukum Nasional di Indonesia. Jurnal Wawasan Yuridika, 3(2), 135-154.

Seff, S. M. (2015). Progresivitas Hukum Dalam Fatwa Dewan Syariah Nasional (Kajian Terhadap Penerapan Qawâ'id Al Fiqhiyyah (Methods Of Jurisprudence) Dalam Fatwa Dewan Syariah Nasional).

Sijistânî, A. D. al. (1969). Sunan Abu Dawud. Beirut: Dar al Kitab al-Arabi.

Ulya, H. N. (2018). Penerapan Akad Ijarah Muntahiya Bittamlik (IMBT) pada Transaksi Lembaga Keuangan Syariah. El-Wasathiya: Jurnal Studi Agama, 6(1), 21-38.

Yasin, M. N. (2014). Progresifitas Formulasi Hukum Ekonomi Syariah Di Indonesia. Journal de Jure, 6(2). 